\title{
Editorial
}

\section{L'AVENIR DES CENTRES UNIVERSITAIRES FRANCOPHONES EN MILIEU MINORITAIRE}

\section{PAUL RUEST*}

L'état déplorable des universités ou des centres universitaires francophones situés à l'extérieur du Québec est largement ignoré au Canada. Sauf pour l'Université de Moncton au Nouveau-Brunswick qui a connu au cours des dernières années d'heureux développements au niveau de sa programmation, les autres centres universitaires francophones en milieu minoritaire font face à des difficultés qui semblent presqu'insurmontables. Qu'ils soient totalement autonomes tels que l'Université Sainte-Anne en Nouvelle-Ecosse ou affiliés académiquement à une grande université dont ils sont co-fondateurs comme c'est le cas pour le Collège universitaire de Saint-Boniface au Manitoba ou encore, une partie intégrale d'une université anglophone (La faculté Saint-Jean à l'Université d'Alberta), tous connaissent une problématique bien différente du reste des universités canadiennes. C'est du moins la constatation que je suis en mesure de faire après avoir passé sept ans à la direction d'un de ces établissements, période pendant laquelle j'ai eu l'occasion de me familiariser avec les préoccupations particulières de ces établissements universitaires "minoritaires". Il me semble opportun de présenter cette problématique et de proposer certaines solutions qui permettraient d'assurer un meilleur avenir à ces établissements.

Les centres universitaires francophones en milieu minoritaire sont généralement issus de collèges dirigés par des communautés religieuses catholiques et offrant un cours classique axé sur les humanités et les langues (latin, grec et français). La programmation offerte visait à préparer des candidats soit pour le clergé ou les professions libérales. Ces premiers collèges catholiques et francophones étaient bien loin de recevoir un encouragement politique et financier de la part de gouvernements provinciaux qui s'empressaient à bannir l'usage du français et l'enseignement religieux des écoles. Ils étaient donc des établissements scolaires privés financés strictement par le clergé ainsi que par la population francophone dont les enfants fréquentaient ces collèges. Au cours des années ' 60 , la situation était devenue intenable. Alors que les universités non-confessionnelles touchaient depuis déjà plusieurs années des subventions gouvernementales de plus en plus importantes pour assurer leur fonctionnement, les communautés religieuses n'avaient ni les ressources humaines, ni les ressources financières requises pour assurer à elles seules la bonne marche de leurs établissements. On reconnaissait de plus le besoin de donner aux laïcs une plus grande place dans la gestion de leurs

*Recteur du Collège universitaire de Saint-Boniface 
collèges. A l'intérieur de quelques années, des institutions étaient léguées à des conseils d'administration laïcs, abandonnant ainsi en quelque sorte leur caractère confessionnel sans pour autant diminuer leur caractère francophone. D'autre part, le Canada devenait de plus en plus sensible au besoin de se donner un caractère bilingue suite aux travaux de la Commission royale d'enquête sur le bilinguisme et le biculturalisme. Celle-ci dénonçait le traitement déplorable réservé à la minorité francophone hors Québec et encourageait les autorités politiques à faire preuve d'une plus grande ouverture d'esprit. Ce n'est qu'à ce moment que les gouvernements acceptèrent de venir en aide aux établissements universitaires francophones en milieu minoritaire, une aide timide qui se limitait trop souvent à simplement maintenir un niveau d'opération basé sur un régime d'austérité financière qu'avaient dû s'imposer les communautés religieuses au cours des années précédentes. C'est donc dire que ces collèges étaient voués à un état de pauvreté qui ne leur permettait pas de se développer comme ils auraient dû le faire, au moment même où les universités anglophones de leurs provinces respectives avaient accès aux fonds nécessaires pour se donner de nouveaux programmes et améliorer leurs services en général. Ces centres universitaires sont encore aujourd'hui prisonniers de leur passé.

L'université francophone en milieu minoritaire doit poursuivre sa mission d'enseignement en français dans un contexte social, linguistique et politique qui est défini et contrôlé par une majorité unilingue anglophone qui ne lui reconnaît pas toujours sa raison d'être. Au risque de déplaire à certains, force nous est d'admettre que dans plusieurs régions anglophones du Canada la présence même d'institutions francophones suscite encore des sentiments d'hostilité de la part d'une population anglophone xénophobe. Et ces sentiments sont généralement reflétés au niveau des élus chargés de représenter la pensée et les souhaits de leurs électeurs. L'université francophone en milieu minoritaire doit souvent oeuvrer dans un climat qui au mieux est indifférent à son existence ou au pire, carrément hostile. Inutile de dire que dans un tel contexte, il lui est difficile d'obtenir un appui financier convenable pour s'acquitter de ses responsabilités. La population anglophone ne comprend pas toujours facilement les aspirations de la minorité francophone. On n'hésite pas à la reléguer au rang des "autres ethnies", refusant de lui reconnaître son statut privilégié au sein du Canada. Il s'ensuit qu'on accepte mal de contribuer un financement supplémentaire pour le maintien de programmes en français destinés à un petit nombre d'étudiants francophones, lesquels programmes sont déjà disponibles dans les autres universités anglophones de la province. On comprend difficilement qu'il soit nécessaire de créer des programmes universitaires nouveaux et peut-être différents pour répondre aux besoins spécifiques d'un groupe minoritaire francophone. Les schèmes conceptuels de la majorité favorisent davantage l'efficacité en termes de dollars et de nombres que les besoins de developpement éducatif d'un groupe minoritaire défavorisé. C'est là une réalité évidemment des plus frustrantes mais aussi des plus importantes avec laquelle l'université francophone en milieu minoritaire doit conjuguer. Elle se retrouve donc souvent dans un contexte socio-politique qui l'oblige à consacrer 
une partie importante des ses énergies à défendre sa raison d'être auprès d'autorités politiques et institutionnelles qui entretiennent généralement peu d'affinité avec elle.

Une autre dimension de la problématique de l'université en milieu minoritaire a trait à sa population étudiante. Le statut socio-linguistique des Francophones du Canada en est un de minoritaire. Ceux-ci sont minoritaires sur le continent nord-américain, ils le sont au Canada et, sauf pour le Québec, ils le sont dans chacune des provinces de leur pays. Dans plusieurs situations, ils forment moins de $5 \%$ de la population provinciale. Cette situation fait en sorte qu'ils sont constamment soumis aux influences de la langue anglaise et d'une culture nord-américaine anglophone. La survie de leur propre langue et culture est inévitablement source d'inquiétude. Le contexte social reflète quotidiennement cette réalité: à l'extérieur du Québec, les contacts et les communications se font en anglais, dans la langue d'une majorité anglophone encore largement unilingue. Cet état de faits favorise d'une part l'assimilation au groupe majoritaire et a pour résultat de rendre encore plus démographiquement minoritaires les groupes francophones. Et au fur et à mesure que le bassin de population diminue, les inscriptions à l'université baissent, mettant ainsi en péril les programmes établis et rendant presque impensable la possibilité d'établir de nouveaux programmes. D'autre part, l'usage limité de la langue française mène inévitablement à un appauvrissement graduel de la langue maternelle chez les Francophones. Il n'est donc pas surprenant de constater que les Francophones en milieu minoritaire qui s'inscrivent à l'université accusent des faiblesses marquées dans la maîtrise même de leur langue maternelle. L'université hérite donc de responsabilités pédagogiques supplémentaires. Elle doit prévoir la mise en place de mesures qui aideront les étudiants à améliorer leur compétence linguistique et à regagner une certaine confiance dans l'usage de leur langue maternelle. De plus, l'enseignement des différentes disciplines devra être sensible au milieu minoritaire duquel sont issus les étudiants. Sans pour autant sacrifier les connaissances universelles des disciplines en question, les programmes d'enseignement devront être adaptés de façon à susciter une prise de conscience chez les étudiants de leur situation particulière, les engageant dans une réflexion qui les conduira à s'intéresser activement au sort de leur communauté. Car il faut bien le dire, l'université en milieu minoritaire ne peut se soustraire à sa responsabilité sociale: sa propre survie est intimement liée à la survie de la communauté qu'elle est appelée à servir.

D'autre part, cette même université connaît des problèmes internes qui se rattachent directement aux circonstances dans lesquelles elle se retrouve. Elle est d'abord vouée à demeurer très petite à cause de ses effectifs restreints d'étudiants. Et le jeu des nombres fait en sorte qu'elle doit s'acquitter de ses responsabilités d'enseignement, de recherche et de service à la communauté avec un montant très limité de ressources humaines et matérielles. Souvent on retrouvera un seul professeur dans une discipline donnée, responsable d'offrir cinq ou six différents cours sur un cycle de deux ou trois ans. Ce même professeur sera appelé à représenter à lui seul sa discipline sur divers comités tant au sein de l'université 
qu'à l'extérieur. Enfin, il sera constamment invité à se sendre disponible à la communauté afin qu'elle puisse profiter de ses compétences professionnelles. Il n'est pas surprenant de constater qu'un tel professeur se sente souvent surchargé, mais pire encore, qu'il souffre d'un profond sentiment d'isolement. Il n'a pas facilement accès à des collègues dans sa discipline, il ne peut pas partager quotidiennement avec d'autres personnes qui oeuvrent dans son domaine. Il risque en somme de perdre de vue les nouvelles orientations de sa discipline à cause des exigences et des limites que lui impose son milieu de travail. D'autre part, l'université francophone en milieu minoritaire éprouve d'énormes difficultés à se doter des ressources matérielles nécessaires pour bien s'acquitter de sa mission d'université. Ainsi elle ne pourra pas toujours offrir à ses étudiants les ressources bibliothécaires souhaitées ou les dispositifs nécessaires pour promouvoir et faciliter les projets de recherche. Située en milieu anglophone, elle n'a pas facilement accès à des ressources francophones pour l'aider à bien s'acquitter de sa mission. Elle doit soit se contenter de ce qui est disponible en anglais seulement, ou bien accepter de dépenser des sommes exorbitantes pour les importer ou les créer de toute pièce.

Il n'existe évidemment pas de recette magique qui saurait à elle seule guérir tous les maux de l'université francophone en milieu minoritaire. Celle-ci peut cependant faire appel à différents éléments de solution ou palliatifs qui sont à sa portée et qui peuvent venir alléger certaines de ses difficultés. A mon avis, elle doit s'attaquer prioritairement au problème de l'isolement. Elle aurait ainsi avantage à accentuer dans son programme d'enseignement une approche pluridisciplinaire plutôt que d'accepter une approche traditionnelle qui favorise trop souvent le cloisonnement des différentes disciplines. Cette approche encouragerait le personnel enseignant à reconnaître la place et la contribution des différentes disciplines dans un programme d'enseignement universitaire destiné à développer à la fois les connaissances et la pensée critique chez ses étudiants. On pourrait ainsi entreprendre une action beaucoup plus cohésive et compréhensive pour traiter des difficultés linguistiques et d'identification culturelle que rencontrent les étudiants issus d'un milieu défavorisé. Mais tout aussi important, ce décloisonnement des disciplines favoriserait l'échange entre professeurs de différents secteurs et pourrait éventuellement conduire à des expériences pédagogiques à la fois innovatrices et stimulantes, ou encore à des projets de recherche pluridisciplinaires des plus intéressants. Cette approche aurait de plus le mérite de mettre en perspective le rôle des différentes disciplines dans la mission de l'université, soulignant à la fois la complémentarité des disciplines et leur apport distinctif. Il va sans dire qu'une telle approche permettrait aux professeurs de se sentir moins isolés au sein même de l'université. Il s'agit là d'un premier pas seulement. L'université en tant qu'établissement devra trouver des moyens imaginatifs pour se rattacher à d'autres centres universitaires francophones qui sont en mesure de l'appuyer dans sa mission. Les nouvelles technologies ont le potentiel nécessaire pour faciliter ce lien. D'ailleurs, la création toute récente d'un réseau canadien d'éducation postsecondaire francophone à distance souligne bien clairement la 
volonté des universités francophones canadiennes de mettre en commun certaines de leurs ressources. Une participation active de l'université francophone en milieu minoritaire à un tel réseau lui donnera l'occasion d'avoir accès aux programmes d'enseignement des autres universités avec toutes les retombées positives que cela comporte. Le partage de ses propres ressources avec d'autres centres universitaires et la possibilité de rendre ses cours accessibles à une clientèle étudiante répartie d'un coin à l'autre du pays aura pour effet de revaloriser ses professeurs. Ceux-ci pourront éventuellement établir des contacts avec de nouveaux collègues pour soit partager des méthodes pédagogiques, des contenus de cours ou même former des équipes de chercheurs. Ce faisant l'université se donnera une ouverture qui dépassera la dimension de son milieu traditionnel tout en se sentant mieux épaulée dans la poursuite de sa mission.

Le nombre restreint d'étudiants qui choisissent de fréquenter l'université francophone en milieu minoritaire menace l'avenir de celle-ci. A mesure que la population francophone s'effrite sous l'impact de l'assimilation, l'université se retrouve devant un bassin de population de plus en plus réduit mais dont les besoins dans le domaine de l'éducation postsecondaire demeurent tout aussi variés que dans le passé. Inutile de dire que les universités en milieu minoritaire doivent se donner des outils efficaces de recrutement pour encourager les étudiants francophones des écoles sécondaires à poursuivre des études universitaires en français. C'est un fait bien connu que les Francophones hors Québec accusent un taux de participation aux études universitaires qui est inférieur à la moyenne nationale; l'université se doit de trouver les moyens nécessaires pour corriger cette situation. Elle doit d'abord se montrer à la fois intéressée et accessible à cette clientèle en multipliant les contacts avec la communauté afin de démystifier en quelque sorte ce monde universitaire qui s'avère souvent trop intimidant. Elle aurait de plus avantage à ne pas limiter ses campagnes de recrutement à la clientèle traditionnelle que représentent les nouveaux diplômés des écoles secondaires. Elle doit viser plus large en trouvant des façons d'intéresser de nouvelles clientèles, telles que les femmes au foyer, les personnes âgées ou les professionnels en exercise désireux de se perfectionner ou de se recycler. C'est d'ailleurs dans cette perspective que l'université a avantage à se doter d'un secteur destiné à l'éducation permanente qui lui permettra d'offrir une variété de cours avec ou sans crédits universitaires qui sauront attirer une plus grande participation.

Les diplômés des programmes d'immersion sont une autre clientèle cible pour l'université francophone. Il s'agit là d'une solution au problème des nombres qui offre la possibilité d'être doublement gagnante tout en comportant, il faut bien le dire, certains risques. D'une part, les programmes d'immersion connaissent une croissance phénoménale au Canada en promettant de rendre bilingues des étudiants unilingues anglophones. Les diplômés de ces programmes obtiennent effectivement des compétences linguistiques intéressantes en français sans pour autant pouvoir affirmer, comme certains éducateurs trop enthousiastes se permettent de le faire, que tous deviennent "parfaitement bilingues". Au contraire, le niveau de bilinguisme atteint à la fin du cours secondaire varie d'un individu à 
l'autre, reflétant souvent le montant de temps et la qualité des expériences vécues dans la langue seconde. Plusieurs possèdent une connaissance suffisante pour entreprendre des études universitaires dans cette langue et auraient avantage à le faire pour rehausser leur niveau de compétence en français. Ils auraient surtout avantage à fréquenter un milieu universitaire francophone qui leur donnerait l'occasion de véritablement vivre en français au lieu de se limiter à un milieu artificiel tel que l'école d'immersion ou encore à quelques cours en français au sein d'une université anglophone. Ils seraient ainsi mieux en mesure de développer leurs compétences linguistiques tout en s'exposant à la culture qui se rattache à cette langue. Au lieu de réduire leur souci de bilinguisme à l'apprentissage de mécanismes linguistiques, on leur donnerait l'occasion d'y ajouter la dimension culturelle, les sensibilisant ainsi aux différentes facettes de la francophonie canadienne. Ce serait en quelque sorte une façon de rapprocher les deux grandes solitudes canadiennes tout en leur permettant de s'entraider de façon bien concrète. D'une part, les diplômés des programmes d'immersion viendraient augmenter sensiblement les inscriptions de l'université francophone, lui permettant ainsi de mieux rentabiliser sa programmation et de se donner éventuellement de nouveaux programmes. D'autre part, l'université francophone donnerait à ceux-ci l'occasion d'atteindre ce niveau de bilinguisme hautement recherché pour pouvoir travailler avec confiance et efficacité en français, lequel niveau les diplômés d'immersion n'ont pas normalement atteint à la sortie du secondaire. Il est bien évident que cette approche comporte certains risques, plus particulièrement le risque pour l'université de perdre son caractère francophone en accueillant une clientèle étudiante majoritairement anglophone. C'est un risque qu'elle devra cependant prendre et surtout prévoir. Il lui faudra sans dout accentuer sa programmation culturelle et affirmer ainsi davantage son caractère francophone. Il lui faudra peut-être établir des critères d'admission qui tiendront compte de cet aspect tout en imposant des normes linguistiques qui encourageront chez tous ses étudiants, francophones ou francophiles, l'usage du français. Les expériences tentées à date semblent positives en ce sens qu'elles contribuent sensiblement au perfectionnement linguistique et à la sensibilisation culturelle des étudiants dont le français n'est pas la langue maternelle, à condition évidemment qu'ils possèdent au départ une certaine compétence en français, sans pour autant diminuer le caractère francophone de l'établissement.

Plusieurs des mesures mentionnées plus haut permettront aux centres universitaires francophones en milieu minoritaire de rehausser leur image publique. Au lieu d'être continuellement perçus par la population de leurs provinces respectives comme étant tout simplement de petits centres universitaires réservés exclusivement à la francophonie, ils viendront à se gagner le statut de centres universitaires de langue française accessibles à toute personne désireuse et capable de poursuivre des études universitaires en français. Ils pourront s'afficher comme un atout important sur la scène de l'éducation postsecondaire de leur province tout en augmentant de façon non-négligeable leur appui social et politique. Les autorités responsables du financement des établissements universitaires ne pourront faire 
autrement que de reconnaître leur domaine d'excellence et l'importance de leur contribution particulière, surtout dans un contexte politique comme celui du Canada.

Les solutions avancées plus haut n'ont certes pas le mérite d'être ni exhaustives ni sans difficulté. Elles ont cependant été tentées avec succès à différentes endroits; à titre d'exemple, le Collège universitaire de Saint-Boniface a réussi, à partir de ces mesures, à doubler ses inscriptions au niveau des programmes universitaires réguliers et à quadrupler la participation dans le domaine de l'éducation permanente sur une période de seulement sept ans. Il s'est de plus acquis une solide réputation au Manitoba comme le centre d'éducation postsecondaire de langue française de la province et commence à toucher l'appui financier dont il a besoin pour offrir à sa clientèle étudiante les services auxquels elle a droit. Il faut cependant ajouter que les efforts du Collège ont été appuyés par des instances gouvernementales et une commission des subventions aux universités qui font de plus en plus preuve de sensibilité et d'ouverture d'esprit à l'endroit de l'éducation en langue française. On peut donc entretenir l'espoir que les centres universitaires francophones à l'extérieur du Québec connaîtront des jours meilleurs, à mesure que les attitudes sociales et politiques évolueront et qu'ils choisiront de s'attaquer résolument à la problématique complexe qui les confronte.

\section{THE FUTURE OF FRANCOPHONE UNIVERSITY CENTRES IN A MINORITY ENVIRONMENT}

\section{PAUL RUEST*}

It's a fact not widely known in Canada, but French-language universities and university centres outside Quebec are in a sorry state. Except for the University of Moncton which has made some fortunate new developments in programming over the last few years, francophone universities in English Canada are faced with problems that seem almost insurmountable. Whether they be autonomous like Nova Scotia's University Sainte-Anne, affiliated with a large university of which they are co-founders, as is the case with Manitoba's Collège universitaire de Saint-Boniface, or an integral part of an English-language university (La faculté Saint-Jean at the University of Alberta), they all grapple with issues not shared by the other Canadian universities. This observation is made after seven years at the head of one of these institutions, years during which I had the opportunity to familiarize myself with the particular concerns of "minority" institutions. I think the time is ripe to present the issues at hand and to propose certain solutions which would guarantee these establishments a better future.

Most of the francophone university centres outside Quebec were founded by Catholic religious orders. Their purpose was to prepare candidates for the 
priesthood or the various professional occupations and they offered a classical education centred around the humanities and the study of Latin, Greek and French. Being both French and Catholic, these institutions were hardly likely to get financial or political support from their provincial governments at a time when these governments were hastening to banish French usage and religious instruction from the schools. They were thus private institutions financed strictly by the clergy and the French population whose children attended them. By the sixties, this situation had become untenable. Whereas the non-confessional universities had for several years been receiving increasingly generous government subsidies to ensure their operation, the religious communities by themselves no longer had the human or financial resources to do the same. They were also becoming aware of the need to give the lay community a larger role in the college administration. Within several years, the colleges were in fact turned over to lay boards of governors - an act which deprived them of their confessional nature without diminishing in any way their French character. Canada, on the other hand, was becoming more aware of the need to acquire a bilingual character as a result of the work of the Royal Commission of Inquiry on Bilingualism and Biculturalism. The Commission denounced the treatment of the francophone minority outside Quebec and challenged politicians to show more openness. At this point, the provinces finally agreed to help out francophone university centres but their meagre help served most often to simply maintain a level of operation based on austerity measures the religious communities had been obliged to impose several years before. Thus, at the same time that the anglophone universities were being funded to add new programs and generally improve services, francophone universities in the same provinces were condemned to a state of poverty which did not allow them to develop likewise. Francophone universities today are prisoners of their past.

The francophone university in a minority environment is obliged to pursue its educational objectives in a social, linguistic and political context defined and controlled by a unilingual anglophone majority which doesn't always recognize its 'raison d'être'. At the risk of unsettling some people, it must be admitted that there are regions of Canada where even the presence of francophone institutions excites hostility on the part of a xenophobic anglophone population. Moreover, these feelings are generally reflected at the level of elected officials charged with representing the thoughts and wishes of the electorate. The francophone university often has to operate in a climate which is at best indifferent to its existence, and sometimes quite hostile. Needless to say, obtaining suitable financial support in this context is fraught with difficulty. The anglophone population does not always readily understand the aspirations of the francophone minority. It tends to put French Canadians in the category of "other ethnic groups" - effectively ignoring their privileged status in Canada. It follows that English Canadians find it difficult to accept subsidizing programs in French when these programs are already available in their province's anglophone universities. They don't see it necessary to create new and maybe different programs in order to respond to the specific needs of the francophone community. The mental framework of the majority 
L'avenir des centres universitaires francophones en milieu minoritaire

favours efficiency in dollars and in numbers over the educational development of a disadvantaged minority. This is obviously one of the most frustrating realities with which the university must grapple, as well as being one of the most important. The francophone university in a minority environment often finds that it is obliged by its socio-political context to spend a large portion of its energy defending its 'raison d'être' before politicians and bureaucrats who have little affinity for its goals.

Another issue facing the university in a minority environment concerns its student population. The socio-linguistic status of French Canadians is that of a minority. They are a minority group in North America, a minority group in Canada and, except for Quebec, within each of their provinces. In some provinces, they make up less than $5 \%$ percent of the total population. As a result of this situation, francophones are constantly subject to the influence of the English language and that of North American culture. Inevitably, the survival of their own language and culture is a source of concern in a social context where daily business and communications are carried out in the language of the still largely unilingual anglophone majority. On the one hand, these circumstances encourage assimilation into the majority group, thereby rendering francophones even more of a demographic minority. As the population decreases, university enrollment drops, threatening the future of existing programs and making the possibility of creating new programs inconceivable. On the other hand, the limited use of French by francophones leads inevitably to a gradual decline in its quality. It's therefore not surprising to note that minority francophones enrolling in university have pronounced weaknesses in their command of their maternal language. The university thus inherits additional teaching responsibilities. It must plan on taking measures that will help students improve their linguistic ability and regain confidence in using their mother tongue. In addition, the teaching of different disciplines must take into account the minority situation from which the students come. Without sacrificing the fundamental subject matter of the disciplines in question, curricula must be adapted in such a way as to promote among students an awareness of their special status, engaging them in a reflective process which will lead them to take an active interest in the fate of their community. For - it has to be said - the university cannot shirk its social responsibility; its own survival is intimately tied to the survival of the community it is called upon to serve.

This same university is furthermore confronted by internal problems directly related to the circumstances in which it finds itself. In the first place, it is destined to remain very small because of its limited projected enrollment. And the numbers game ensures that the university has only a limited amount of human and material resources with which to meet its teaching, research and community service obligations. In any given discipline, a single professor is often required to teach five or six courses in a two- or three-year cycle. The same professor is called upon to represent his discipline on various committees both within and without the university. Finally, he is constantly asked to make himself available to the community at large so that it may benefit from bis expertise. It is not surprising that 
a professor in this situation should feel overworked or, even worse, suffer from a profound sense of loneliness and isolation. He doesn't have easy access to colleagues in his discipline meaning he can't share on a daily basis with other persons working in his domain. In short, the demands and limitations imposed by his work environment cause him to run the risk of missing out on new developments in his field. The minority francophone university also has enormous difficulty obtaining the material resources necessary for it to fulfill its academic goals. Thus, it can't always offer its students the desired library resources, nor the equipment necessary to promote and facilitate research projects. Located in an anglophone environment, it doesn't have easy access to resources in French and must content itself with material that is available in English or else agree to spend exorbitant sums importing French materials or creating them from scratch.

Obviously, there is no magic formula which can cure all the ills of the minority francophone university. There are, however, some partial solutions or palliatives at hand which could relieve some of the symptoms. In my opinion, priority should be given to the problem of isolation. Rather than adopt the traditional approach that too often favours the compartmentalization of disciplines, the curriculum should emphasize a multidisciplinary approach to education. The teaching staff should be encouraged to recognize the role different disciplines can play in a program designed to develop both knowledge and a capacity for critical thinking. They would thus be able to formulate a more cohesive response to the problems of language and cultural identity facing students from a disadvantaged environment. But, just as important, this decompartmentalization of disciplines would encourage communication between professors in different fields and could potentially lead to innovative experiments in teaching methods, or even to multidisciplinary research projects of the most stimulating kind. The multidisciplinary approach, by pointing out both the complementarity and the uniqueness of each discipline's contributions, would have the additional advantage of putting in perspective the role of these disciplines in the university's larger mission. It goes without saying that professors would feel less isolated even within their own institutions. But this is only a first step. The university as an institution will have to find imaginative ways in which to link itself to other francophone university centres in a position to help it achieve its goals. The new technology has the potential to facilitate this link. Besides, the recent creation in Canada of a long-distance network for postsecondary French-language education clearly demonstrates the willingness of francophone universities to share some of their resources. Active participation in this kind of network will give the francophone university in a minority environment access to the academic programs of other universities and much more. The possibility of sharing its own resources with other universities and of making its courses available to students all across the country will increase the value of its teaching staff. Professors themselves will be able to make new contacts with whom to share teaching methods or course content, or even form research teams. Through networking, the university will be able to reach far beyond the 
limits of its traditional environment while benefiting from the increased support it receives in return.

The future of the minority francophone university is threatened by the limited number of students choosing to attend. As the francophone population erodes under the impact of assimilation, the university is faced with a shrinking client population whose post-secondary educational needs remain as varied as ever. Needless to say, francophone universities in English Canada will have to adopt some efficient recruiting methods in order to convince francophone students coming out of high school to pursue their university-level education in French. It's a well-known fact that the rate of university enrollment among francophones outside Quebec is lower than the national average; the universities owe it to themselves to find ways to correct this situation. In the first place, the university should multiply its contacts within the community. By showing itself to be both interested in, and accessible to, this potential clientele, it will help demystify a world many people find intimidating. It would also be to the university's advantage not to limit its recruitment campaign to graduating high school students, but to target a wider population that includes housewives, senior citizens, and professionals wanting either to upgrade their present skills or retrain for new occupations. By creating a department of continuing education that offered a variety of both credit and non-credit courses, the university would be able to attract greater participation than it does now.

Another potential target group for the francophone university consists of the graduates of French Immersion. This solution, though it would solve the problems of declining enrollment and underfunding, admittedly carries with it certain risks. Immersion programs are growing ever more popular in Canada on the strength of their promise to make unilingual anglophones bilingual. In fact, the graduates of these programs have acquired a certain competence in French but it cannot be said, as some over-enthusiastic educators would have us believe, that all are "perfectly" bilingual. On the contrary, the degree of bilingualism attained by the end of high school varies from one individual to another, depending on the amount of time spent and the quality of experience lived in the second language. Many graduates are competent enough to undertake university-level studies in French and it would be in their interest to do so in order to further increase their fluency. But rather than limit themselves to the artificial environment of an immersion program or a handful of courses given in French at an anglophone university, they would be better off enrolling in a francophone university where they would have the opportunity of actually living in French and experiencing the culture that goes with it. The process of becoming bilingual would thus not be confined to simply learning the mechanics of the French language but would have a cultural dimension as well, sensitizing anglophone students to the different facets of French-Canadian culture. This would be one way of bringing the two solitudes closer while at the same time giving them a chance to tangibly help one another. On the one hand, the influx of immersion school graduates would increase 
enrollment substantially, thereby helping to defray the cost of existing programs and possibly enabling the francophone university to add new ones. On the other hand, anglophone students would have the opportunity to attain the much sought-after level of bilingualism that will enable them to work in French efficiently and with confidence. It is evident that this strategy carries risks, not least of which is the chance that, in opening its doors to an anglophone majority, it will lose its francophone character. It is a risk that will have to be taken, however, along with certain precautions. The university will undoubtedly have to increase its cultural programming in order to assert its francophone character more strongly. It may have to establish certain admission requirements as well as impose linguistic norms that will encourage the use of French among francophones and francophiles alike. Experience to date suggests that, given a certain level of competence to start with, this solution contributes to the linguistic proficiency and cultural awareness of students for whom French is not the maternal language without diminishing the francophone character of the institution.

Several of the above-mentioned measures have the potential of improving the francophone universities' public image. Rather than continue to be perceived simply as small academic centres reserved for the provinces' francophones, they will come to have the status of French-language university centres accessible to every person desiring to, and capable of, pursuing university-level studies in French. With social and political support mounting, the universities will be able to bill themselves as being an important asset on the post-secondary scene of their respective province. Especially in a political context like Canada's, the authorities responsible for funding universities will be unable to do otherwise than acknowledge the francophone universities' field of excellence and the special importance of their contributions.

The solutions offered here certainly are not exhaustive, nor are they easy to implement. Various institutions have, however, tried them with success. The Collège universitaire de Saint-Boniface, for example, succeeded in doubling regular course registration and quadrupling continuing education enrollment in only seven years. It has also acquired a solid reputation as the centre of French-language university education in Manitoba and is beginning to receive the financial support it needs to offer its students the services they deserve. It must be added, though, that the Collège's efforts have been aided by government authorities and a university grants commission that are growing increasingly sensitive and open-minded about French-language education. We can therefore hope that, as social and political attitudes evolve and the universities themselves resolve to attack head-on the problems confronting them, francophone universities in a minority environment will see better days. 